\title{
Race - Consciousness in Selected Poems by Paul Laurence Dunbar
}

\section{A research submitted by: Asst. Lecturer: Shereen Shehab Hemed}

\section{Abstract}

Some critics believe that Paul Laurence Dunbar, the African American poet, does not concentrate in his writing on his race or blackness but rather he concentrates on his nationality as an American poet. It is true that Dunbar tried hard to achieve this aim during his life time but he found it impossible to transcend completely the influence of his race on his poetry.

A considered reading of some of Dunbar's poems affirms his loyalty to the black race and his pride in its achievements, as well as his righteous anger over racial injustice.

$$
\begin{aligned}
& \text { الوعي العرقي في قصائد مختارة للثاعر بول لورنس دنبر }
\end{aligned}
$$

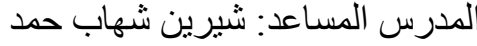

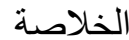

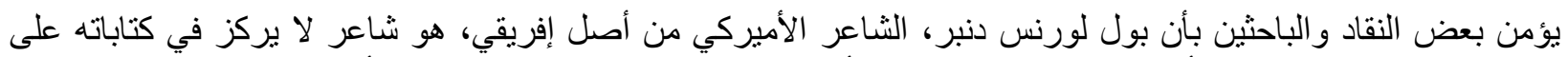

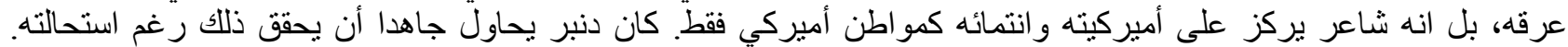

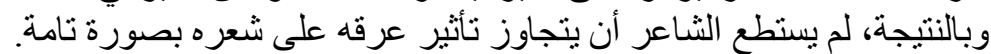

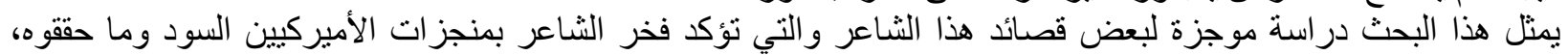

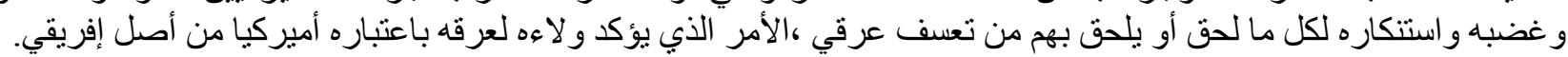

It is better to clarify the meaning of Race-consciousness for readers. The term denotes a consciousness of race. Paula Stewart Brush defines it clearly:

Race consciousness means knowing that and how the personal is political, that and how the possibilities of one's existence are enmeshed with social conditions...race is understood as a central constituent of identity, that race is...recognized as a basis of domination or privilege, and that racism becomes a point of resistance. 1

It is also defined as :

The tendency towards sentimental and ideological identification with a racial group. For the individually race conscious, the race becomes an Object of loyalty, devotion, and pride. 2

A race conscious poet is aware of his states in relation to a dominant class, nationality or race with which it is in conflict. He deals with the harsh aspects of life - especially the Negro life. This leads to racial realism, a term which

refers to various literary representations of the "race," including African Diasporan protagonists, settings, customs, vernacular, polemics, and other signifiers often used to classify a text as African American

literature. 3

In his essay "The Poet Laureate of The Negro Race," W.S Scarborough believes that there are three facts which influence the literature of people in all nations: the race of the writer, the epoch in which he lives, and his environment.4 Paul Laurence Dunbar, the subject of this research, is not an exception. He is a poet who is influenced by all these facts.

Paul Laurence Dunbar (1872-1905), an African American poet and a son of slaves, is a poet who "felt for his race, and as his race he sang with the heart and tongue of his people." $5 \mathrm{He}$ produced twelve books of poetry, four books of short stories, a play and five novels. Dunbar lived in a period during which the black had gained their freedom, but they were still fighting for equality. The Ku Klux Klan was formed to oppress the African Americans and to prove that white men were superior. "Blacks were discriminated against in practically all areas and localities of American life, and efforts are made to re-establish slavery." 6 
Like many writers, he was influenced by his epoch and environment and this had a strong effect on his works. In his lifetime, Dunbar was considered as a symbol of African American and a representative of his race. He has been criticized for his idealized poems which include stereotypical slave images such as the faithful slave, the black mummy who is devoted to the master`s children, and the uncle who tells tall stories. 7 But a close reading of his poetry reveals that his writing is a protest and a rejection of the dominant racial stereotypes of the day. He is, like many American - Negro, influenced by his race and all that is related to it. This view is expressed by Alain Locke in his essay "The Negro in America culture;" he says:

In the case of the American Negro the sense of race is stronger than that of nationality; and in some form or other is a primary factor in the consciousness of the Negro poet. 8

Some critics argue that Dunbar is not a race - conscious poet and he writes mostly to satisfy the white audience or readers:

Why didn't Dunbar protest more often and more boldly against racist excesses? Did he fear that too much frankness would lose him part of his readership, which was almost entirely white? 9

Like many African American writers, Dunbar has been torn between the conflicting loyalties of race and art. On one hand, he has sought to be a spokesman for his people, and on the other, to be accepted on his merits as a poet. He wanted to be perceived as an American poet rather than a negro poet who is restricted by his race.10 But this does not mean that the poet has totally avoided writing about his race and people. The following pages investigate this claim.

"Sympathy" is a race poem. The poet shows how racism is imprisoning his soul. He compares a bird trapped in a cage to slavery and the pain of no freedom. He feels and understands what is it like to have freedom out of reach:

I know what the caged bird feels, alas!

When the sun is bright on the upland slopes;

When the wind stirs soft through the springing grass,

And the river flows like a stream of glass. 11

The second stanza continues to realize the frustration of the bird as it "beats [its] wing" (1.8) trying desperately to break from its cage "till its blood is red on the cruel bars" (1.9). The poet illustrates the continuous hope of the African American population. Though "his wing is bruised and his bosom sore" (1.16) the bird sings. This song represents the plea for freedom. "It is not a carol of joy or glee,.../ But a plea, that upward to Heaven he flings" $(11.18,20)$. Dunbar`s cage is the racism that he has constantly faced during his time period. Dunbar has found that it is impossible to find any job that could be considered important. He was an elevator boy and his main way of venting his frustration against a discriminatory world was through poetry. 12 The bird`s song in "Sympathy" is like the mask in Dunbar`s poem "We Wear the Mask" which hides pain and real emotions and opinions of the blacks in order not to be hurt in someway. Dunbar uses a mask to hide his emotions and true self. By doing this, he thought of himself as stronger and more able to conquer the racial war being fought everyday. The poet describes the harsh reality of the black race in America and how they hide their grief under a mask for survival strategy towards whites:

We wear the mask that grins and lies,

It hides our cheeks and shades our eyes,

This dept we pay to human guile,

With torn and bleeding hearts we smile,

And mouth with myriad subtleties. (11.1-5)

Dunbar uses "the mask since it was a false deceptive role-playing... It maintained a sense of empowerment in a racial society." 13 The mask lies to the whites and the person who wears it. The poet uses irony as he thinks that the whites are not obliged to "count all our tears and sighs?" (1.17) He recognizes that they are trapped under this mask: "Nay, let them only see us while / We wear the mask" (11.18-19). A poignant line presents an important metaphor which compares the clay to the 
African Americans, "O, but the clay is vile" (1.12). Clay is earthly and moist material but when fired or intensely heated, it becomes hard. So, the African Americans are similar to that clay and this metaphor presents a warning to those who deprive them from their rights in equality. The metaphor asserts that when enraged or fired, the blacks will become hardened to the world and turn on it completely. The race cries and sings to Christ in pain to find peace and equality in this world. "The world dream[s] otherwise," (1.14) unaware of these "tortured souls" (1.10). Dunbar obviously feels that people are blind to the injustice of criminal discrimination. Though implicit, Dunbar`s wrath towards the life of the blacks is the main theme of the poem.

"The Haunted Oak" 14 is another clear protest against racism. Dunbar felt the need to protest against any injustice done to his race. In a lamentful tone, the poet attacks the blacks lynching. Dunbar personifies the tree, the oak, to tell the story of an innocent black man who was "a guiltless victim" (1.8). The tree witnessed how he was hanged on one of its branches "with no care for his innocence" (1.31) since "they`d charged him with the old, old crime" (1.13). This personification of the tree enables the reader to imagine the scene of lynching and feel it:

I feel the rope against my bark,

And the weight of him in my grain,

I feel in throe of his final woe,

The touch of my own last pain. (11.49-52)

The branch withered while the others continue to flourish and this is why the tree is called "The Haunted Oak". In a sharp satire, Dunbar describes those who lynched that "guiltless victim" :

Oh, the judge, he wore a mask of black,

And the doctor one of the white,

And the minister, with his oldest son,

Was curiously bedight. (11.41-44)

These lines reveal the lie of the white justice. The doctor is supposed to be an angel of mercy and the minister is supposed to be a godlike man but here they are criminals. Symbolically, the judge is described as riding "to hunt the deer" (1.58) which refers to the judges' continuous lynching of the African Americans who are similar to the deer, in their innocence. In some of his poems, Paul Dunbar praises those heroes who fought and worked against slavery, such as Frederick Douglass, Mary Britton and Robert Gould Shaw "Frederick Douglass" is an elegy written to praise this great leader of the race. 15

Dunbar utters sentiments that suggest Douglass' importance in the context of the African American fight for freedom. His death caused a "pause" (1.2) in the rushing strife of life. This death saddened 'Ethiopia, the race-mother. "And Ethiopia, with bosom torn / laments the passing of her noblest born" (11.5-6). In his essay "Paul Laurence Dunbar and the African American Elegy," Marcellus Blount states the following:

By figuring Ethiopia as Douglass` mother, an argument about racial identity ensues; the black race is that maternal essence

that Douglass`s presence had embodied.. 16

Douglass comforted, Dunbar suggests, by showing courage in his attacks upon slavery:

For his voice, a fearless clarion, rung

That broke in warning on the ears of men;

For her, the strong bow of his pow`r he strung

And sent his arrows to the very den

When grim oppression held his bloody place

And gloated o`er the mis`ries of a race. (11.13-18)

This leader is a courageous leader and speaker who "was not soft- tongued apologist" (1.19) but he "answered thunder with his thunder, back." (1.30) This same force and power served the black race following the defeat of slavery as Dunbar writes: "The place and cause that first aroused his might / 
Still proved its pow`r until his latest day." (11.43-44) Douglass, for Dunbar and even his race, becomes an inspiring model:

O, Douglass! Thou hast passed beyond the shore,

But still! Thy voice is ringing o'er the gale!

It tells thy race how high her hopes may soar,

And bade her seek the heights, -nor faint- nor fail.

She knows thy guardian spirit will be high;

The "kindling spirit of his battle cry" (1.52) is the spirit that Dunbar and the African Americans need in order to "triumph." (1.53)

In another poem dedicated to the same leader, Dunbar fears that life will continue this way and that change won't be made. He invokes" Douglass" and asks him for help:

Ah, Douglass, we have fall'n on evil days,

Such days as thou, not even thou dids`t know,

Oh, for thy voice high- sounding o'er the storm,

For thy strong arm to guide the shivering bark,

The blast-defying power of thy form,

To give us comfort through the lonely dark.

$(11.1-2,11-14)$

He wants to get out his anger and to make the country realize what is going on around them, but he also has hope for the future that someone will come along and make life better for African Americans.

"To Mary Britton" is another poem inspired by the action of a young negro woman, Mary Britton.17 The first two stanzas are effective in their speech addressed to God in a form of a prayer that asks God to help his oppressed children, the African Americans, who "mourn / In labor and travail." (11.3-4) He asks God to let His power prevail and to

Speed the happy day

When waiting ones may see

The glory-bringing birth !

Break down the hind `ring bars,

And make us free indeed. $\quad(11.5-8,15-16)$

This woman "Whose fearless voice and strong / Rose to defend her race" (11.21-22) becomes another source for inspiring Dunbar and his race: "Give us to lead our cause/ More noble souls like hers" (11.17-18). This poem is not only a prayer but also a protest and denunciation.

Dunbar continues to express his pride and glorification of his race and its heroes in "The Colored Soldiers" Which is also an implied protest against race discrimination. Dunbar, in this poem,

Sing[s] a song heroic

Of those noble sons of Ham

Of the gallant colored soldiers.

Who fought for Uncle Sam! (11.5-8)

Dunbar addresses the white American directly as he begins by reminding whites, at the outset of the war, the services of blacks had been contemptuously refused

In the early days you scorned them,

And with many a flip and flout

Said "These battles are the white man`s,

And the whites will fight them out. 
But they later needed them and "called the colored soldiers [who] answered [their] call." (11.23-24) These soldiers proved themselves to be heroes who "pressed unblanched and fearless / At the very mouth of hell" (11.31-32). Then he mentions many battles in which blacks have taken part and proved their courage. The last two stanzas present the question of equality of the races:

They were comrades then and brothers.

Are they more or less to-day?

They were citizens and soldiers,

And their blood with yours commingling

Has enriched the Southern soil. (11.57-58,61,67-68)

"Ode to Ethiopia" expresses the same glorification but this time to "Mother Race" (1.1), Ethiopia. It is an inspiring poem for freedom:

The plant of freedom upward sprung

And spread its leaves so fresh and young

Its blossoms now are blowing.

Dunbar yearns for a better future in which he and his race gain freedom. Then, the poet praises the nobility of forgetting and forgiving, "Forgot the past and proved them men / So noble in forgiving" (11.51-52). Because of these various themes which serve the case of the African Americans, Dunbar is considered as a poet of his race:

Every person of color should feel under lasting gratitude to our honored poet for the position he won for his people; and the race must never fail to show that gratitude not only for this fact, but for every phase of recognition accorded him by other races. 18

\section{Conclusions}

Paul Laurence Dunbar tried hard to avoid writing race-conscious poetry, yet he has wrote few poems protesting against the mistreatment, violence and discrimination that were victimizing his race. In some poems, he expresses his protest against race distinction directly while in other few poems he hides it and makes it implicit. "The Haunted Oak" is directed to denunciating the lynching of African Americans. "We Wear the Mask" explains how the black are obliged to hide their anger and opinions under a mask. "Sympathy" is a powerful image of empathy with the caged bird that sings. The bird in the cage stands for the blacks who fight for their freedom. Dunbar also praises the African American heroes and searches for similar heroes in his present such as Frederick Douglass and Mary Britton. In most of his poems, there is hope and aspiration which are evident in "Ode to Ethiopia." All the explained poems are proved to be race-conscious poems in which the poet defends his race.

\section{Notes}

1 Mrs.Paul Laurence Dunbar and W.S.Scarborough, Paul Laurence Dunbar:Poet laureate of the Negro Race .( Philadelphia: Reverdy Ransom, 1914), p.25.

2 Paula Stewart Brown, "Problematizing the Race Consciousness of Women of Color," Signs, 27:1 ( Autumn 2001), p.171.

3.W.O. Brown, " The Nature of Race Consciousness," Race, Cultural Groups, social Differences, 1973), p.90. 
4 Jene Jarret, " 'We Must Write like the White Men' : A Race Realism and Dunbar`s Anomalous Fist Novel," Novel : A Forum on Fiction, $37: 3$ ( 2004), p.303.

5 Mrs. Paul Dunbar, p.25

6 Carter Woodson, A Century of Migration ( Washington D.C. : The Association for the study of Negro Life and History, 1918), p. 166.

7 Quoted in Jean Wagner, Black Poets of the United States ( $\mathrm{n} . \mathrm{p}$. : University of Illinois Press, 1973), p.81.

8 Quoted in Cary D. Wintz, Analysis and Assessment; 1940-1979 ( 1996), p. 56.

9 Jean Wagner, p.103

10 Felton O`neal Best," Crossing the Color Line: A Biography of Paul Laurence Dunbar, 1972 1906" (PH.D. dissertation, The Ohio State University, 1992), p.296.

11 Paul Laurence Dunbar, The Complete Poems of Paul Laurence Dunbar ( New York: Dodd, Mead and company, 1922), [All the references to Paul Laurence Dunbar`s poems are from this source ], (1101-4) .

12 Hellen Douglass, Memoriam : Frederick Douglass ( Philadelphia : J.C. Yarston and co., 1997), p. 166 .

13 Marcellus Blount, " Paul Laurence Dunbar and the African American Elegy." African American Review ( June 22 , 2007) .

14 The content is a story told to Dunbar by an old Negro of Howard town whose nephew had been falsely accused of rape. Jean Wagner, p. 102 .

15 Frederick Douglass represented one of the few surviving figures from the historic antebellum link to the black struggle against slavery. Hellen Douglass, pp.168-169 .

16 Marcellus Blount , p.

17 Mary Briton is a teacher in Lexington, Kentucky, who rose up in the state assembly and delivered a passionate speech against a bill providing for segregation in public transport. Jean Wagner, p. 101 .

18 Mrs . Paul Laurence Dunbar, p. 28.

Bibliography

- Best, Felton O`neal. " Crossing the Color Line: A Biography of Paul Laurence Dunbar, 1972 1906." PH.D. dissertation. The Ohio State University, 1992.

- Blount, Marcellus. "Paul Laurence Dunbar and the African American Elegy." African American Review ( June 22, 2007 ).

Carter Woodson. A Century of Migration . Washington, D. c.: The Association for the Study of Negro Life and History, 1918.

- Douglass, Helen . Memoriam : Fredrick Douglass. Philadelphia: J.c. Yarston \& co, 1897. 
Dunbar, Paul Laurence. The Complete Poems of Paul Laurence Dunbar. New York: Dodd, Mead\& company, 1922 .

Brown, W.O. "Race Consciousness Among South Africa Natives." The American Journal of Sociology. 40:.5 (Mar., 1935), pp.569-581.

Brown, W.O. "The Nature of Race Consciousness." Race, Cultural Groups, social Differences. 1973.

Brush , Paula Stewart. "Problematizing the Race consciousness of Women of Color." Signs. 27:1 ( Autumn, 2001 ), pp.171-198 .

Erkerd, Ivery ."A Middle School Approach to Black Literature : An Introduction to Dunbar, Johnson, Hughes \& Angelon."

Jarrett, Gene. " 'We Must Write Like the White Men' : Race Realism and Dunbar's Anomolons First Novel." Novel : A Forum on Fiction 37:3 ( 2004 ), p.303-325 .

Jean Wagner, Kenneth. Black poets of the United States .n.p : university of Illinois presses, 1973.

Johnson, J. Wedon ( ed.) The American Negro Poets ( 1871-1938 ). New York: Harcourt, Brace \& Company, 1922.

Hudsom, Gossie Harold. "Paul Laurence Dunbar : Dialect Et La Negritude." Phylon

( 1960- ), 34 :3 (3rd . Qtr. , 1973), pp.236-247.

Gabbin , Goanne . "Intimate Intercessions in the Poetry of Paul Laurence Dunbar." African American Review. vol.41 ( 22 June 2007 ).

Giltroy, Joseph William . "Understanding Paul Dunbar : A life and Career in Context." M.A thesis. Raleigh: North Carolina, 2007.

Lash, John. "The Race Consciousness of the American Negro Author: Toward a Reexamination of an Orthodox Critical Concept" Social Forces. 28:1 ( oct.1949), pp.24-34.

Mrs. Dunbar, Paul Laurence and Scarborough, W.S. Paul Laurence Dunbar :Poet Laureate of the Negro Race . Philadelphia : Reverdy Ransom, 1914.

Smethurst , James. "Paul Laurence Dunbar and Turn - into - the 20th century African American Dualism." African American Review.( June 22,2007).

Washington, Booker." The Case of the Negro." The Atlantic Monthly ( November 1889 ) .

Wintz, Cary D. Analysis and Assessment, 1940-1979 new york 1996.

Woodson, Carter C. A Century of Migration. Washington: The Association for the study of Negro life and History, 1918.

"Paul Laurence Dunbar: The Rejected Symbol." The Journal of Negro History.11:1 (Jan.1967).

"Paul Laurence Dunbar : a Credit to his race" African American Review (22June, 2007).

"Paul Laurence Dunbar" <URL:http://en. Wikipedia.org/wiki/Paul Laurence Dunbar.>

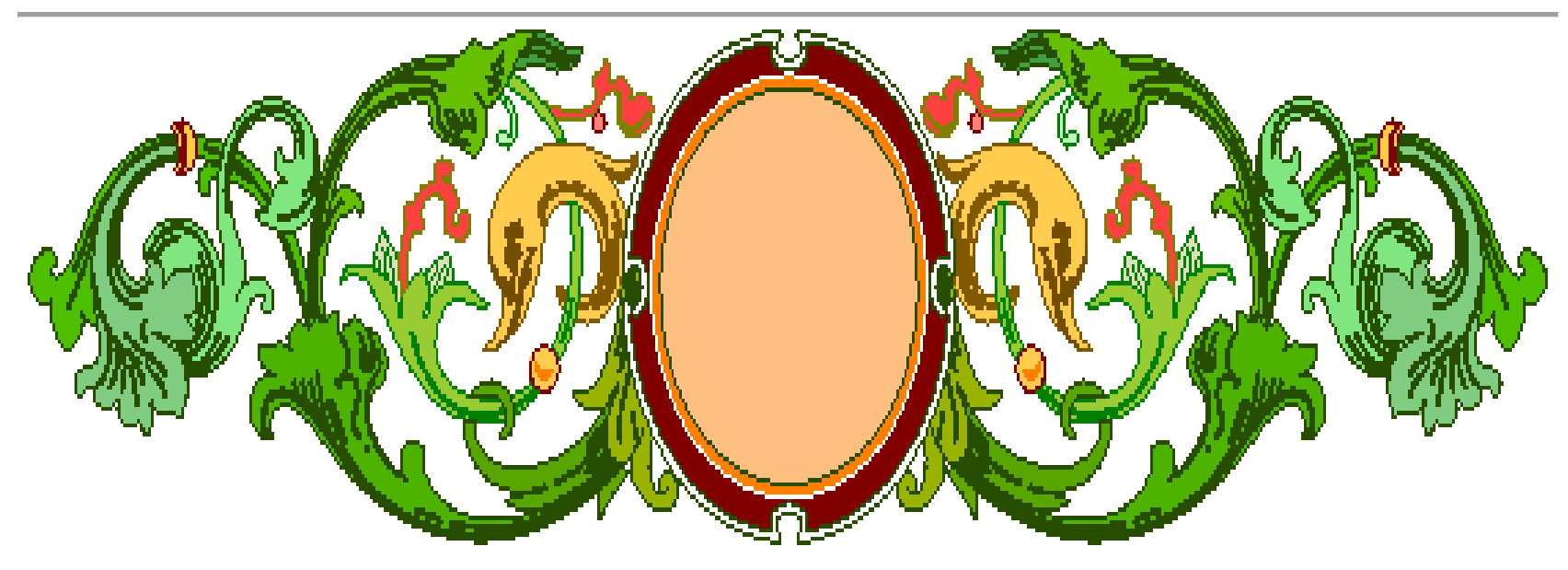

